\title{
Campesino justification for self-initiated conservation actions: a challenge to mainstream conservation
}

\author{
Noga Shanee ${ }^{1}$ \\ Neotropical Primate Conservation, UK/Peru
}

\section{Introduction}

Peru is considered one of the world's megadiverse countries (Rodríguez and Young 2000). The regions of Amazonas and San Martin in the country's Northeast are a central part of the 'Tropical Andes Biodiversity Hotspot', considered the most biodiverse area on earth and a global conservation priority (Myers et al. 2000; Myers 2003). Amazonas and San Martin are home to Peru's three endemic primate species, two of which are considered 'Critically Endangered', the yellow-tailed woolly monkey, (Oreonax flavicauda) and the San Martin titi monkey (Callicebus oenanthe), (Bóveda-Penalba et al. 2009; Mittermeier et al. 2009; Mittermeier et al. 2012; Shanee 2011; Shanee et al. 2013), three known endemic bird species (Schulenberg et al. 2010), ten 'Important Bird Areas' (O'Dea et al. 2006) and 'Endemic Bird Areas' (Stattersfield et al. 1998), and countless endemic plant and invertebrate species (Myers et al. 2000; Rodríguez and Young 2000).

Both of these regions suffer from the highest rates of deforestation in Peru, fuelled by immigration and a lack of government intervention (INEI 2007; Reategui and Martinez 2007; Shanee 2012a). By 2000, according to government publications, Peru had lost 7,172,953 ha of the estimated original extent of its Amazonian forests. The regions with the highest deforestation rates were: San Martin with 1,327,736 ha, equivalent to $25.9 \%$ of its total area and Amazonas with 1,001,540 ha, equivalent to $25.5 \%$ of its total area (PROCLIM/CONAM 2005). Major deforestation started in the 1940s with about 8,000 ha deforested annually in the region. In the 1960s and 1970s, deforestation escalated to an estimated 55,000 ha annually. Recent data show that from 1989-2002, 11,000 ha were cleared annually in San Martin. ${ }^{2}$ No official estimates exist for the Amazonas region. Hunting and wildlife trafficking are also a major problem for wildlife (Shanee 2012b). This article reports on how the rural populations of Amazonas and San Martin justify their own conservation initiatives, finding that these efforts are often ignored by mainstream conservation and in political ecology critiques. More generally, it provides new perspectives on local participation in biodiversity conservation.

The people of these regions are of mixed indigenous and European origins. These are campesinos, impoverished farmers, who suffer land insecurity and deteriorating environmental resources (Loker 1996; Shanee 2012a). Campesinos in Northern Peru farm for subsistence (mainly tubers, corn and beans) and commercially (cattle, rice, coffee, cacao) (Shanee 2012a; Zimmerer 1997). The majority are migrants from the country's northern highlands where an increasing population and the proliferation of mining operations resulted in a scarcity of fertile land, increased land prices and a lack of natural resources such as potable water and firewood (Bebbington and Bury 2009; Bury 2005, 2007; Szablowski 2002). The growing numbers of migrants often invade and settle illegally on forested lands. They are offered no assistance from the government and use poorly adapted farming methods (Bebbington 1990). These increase the effects of micro-climatic changes and land degradation, adding to the pressure on farmers, forcing them to augment their efforts to maintain the same levels of production. This leads to more clearing, uncontrolled burning and more illegal resource use; the consequence of this pressure spirals back on the natural environment (Shanee 2012a).

Throughout South America colonizers of new areas are held responsible for environmental destruction. Nugent (1993) shows that campesino colonists are presented in the literature as maladaptive, with a hunger for more land and forests. They are also blamed for a lack of 'forest culture' and an intrinsic antipathy towards nature (Nygren 2000). Sundberg (1998) gives many examples of state officials and NGOs blaming campesinos for environmental destruction in Guatemala. Loker (1996) writes:

\footnotetext{
${ }^{1}$ Dr. Noga Shanee, Co-Director of the Yellow Tailed Woolly Monkey Project in Peru, run by UK NGO 'Neotropical Primate Conservation' (NPC), 23 Portland Road, Stratford, Manchester, M32 0PH, UK. E-mail: nogashanee "at" gmail.com. I would like to thank Sam Shanee, Stuart R. Harrop, Marcos Diaz Delgado, Sadie Legh, Trisha Davison, Rosa Pineda, Robert Horwich, Jim Igoe, Marita Lozano, Miguel Alva Reategui, Mariella Leo Luna, Alejo Mego, Carlos Bustamante and the Fernandez family. Thank you to all the NGOs, associations, churches, the Ronda Campesina and the many other conservation initiators in Amazonas and San Martin for participating in this study. All contributed to and inspired this work. I thank Neotropical Primate Conservation for funding.

${ }^{2}$ Reátegui García, regional director of Natural Resources and Environmental Management, at the Regional Forum on Forest Politics and Climate Change in Tarapoto, Peru, June 2010.
} 
With the recent 'environmental turn' in development discourse, campesinos have been further demonized as the destroyers of the land, degraders, deforesters, short-sighted abusers of biological resources and otherwise enemies of sustainable development either out of ignorance, desperation or both.

The reputation of campesinos as the destroyers of the environment described in the literature is deeply rooted in the environmental discourses found in Northeastern Peru. It is often used by NGOs and state conservation agents to explain the limited achievements 'on the ground' of many of their conservation initiatives (Shanee 2012a).

The literature offers varied moral and rational reasoning for conservation, which can be divided into anthropocentric and ecocentric categories (Cafaro 2001; Paterson 2006). Anthropocentric ethics are the most prevalent in recent environmental agendas such as the World Commission for Environment Development's sustainable development concept (1987) and resource management plans relying on neoliberal economic ideologies (Palmer 2003; Vaccaro et al. 2013). These emphasize the importance of conserving species with potentially beneficial qualities for humans, including those that attract tourism, game, agricultural varieties and those with medicinal qualities (Paterson 2006). By contrast ecocentric environmental ethics, which are found in Leopold's The land ethic (1970), or the Convention on Biological Diversity (CBDS 2001), stress the intrinsic value of biological diversity and thus the importance of a more holistic approach to conservation. It can be argued that whichever reasoning is used it directly influences the type of protection given.

Brockington et al. (2008) define "mainstream conservation" as the dominant global conservation paradigm, especially evident in the operations of big conservation NGOs (BINGOs), that lead global conservation policy. Their schemes are based on neoliberal ideologies where nature acquires economic value and is commoditized in order to "pay for itself" (Breunig 2006; Büscher and Whande 2007; Hayden 2003; Sullivan 2010). They use the concept of 'win-win solutions', suggesting that economic growth and conservation can enhance each other, bringing solely positive outcomes.

Like many other political ecologists, Igoe and Brockington (2007) notice that mainstream conservation discourse presents local populations as the primary threat to biodiversity. Institutions often employ neoliberal methodologies aimed at preparing local people to enter the global economy through the granting of property rights and capacity building; making them 'competent conservationists.' Under this model existing local environmental knowledge and their own environmental initiatives are frequently ignored (Igoe and Brockington 2007). In addition the conceptualization of nature as a service provider is thought to have contributed to the cultural devaluation of nature, often undermining peoples' connection with, and respect for, local landscapes (Sullivan 2009, 2010).

In practical terms, conservation effectiveness has been increasingly reliant on partnership with local stakeholders since the 1980s (Adams and Hulme 2001; Adams 2004; Brosius et al. 1998; Brown 2002; Western and Wright 1994). Many conventional conservation interventions now promote people-orientated projects, integrating conservation and economic development (Adams 2004; Agrawal and Redford 2006; Jeanrenaud 1998; Vaccaro et al. 2013). These projects are often criticized for failing to implement conservation (Durand and Vázquez 2010; Hutton et al. 2005; Kellert et al. 2000; Kiss 2004; Oates 1999; Terborgh 1999; Wilshusen et al. 2002), as well as failing to achieve sustainable development (Barrett and Arcese 1995; Wainwright and Wehrmeyer 1998). Academic literature relates these failures to:

a) The ideology of perceiving local people as a problem to be addressed rather than real partners in conservation (McShane and Wells 2004);

b) Consistency with 'fortress conservation' methods, using top-down approaches, thus failing to meet proclaimed goals of participation and empowerment (Brown 2002; Cernea and Schmidt-Soltau 2006; Hulme and Murphree 2001; McShane and Wells 2004);

c) Un-sustainability of projects resulting from economic wastefulness (Kiss 2004; McShane and Wells 2004);

d) Dependency on economic incentives that undermine the social and ethical values of nature and conservation (Uphoff and Langholz 1998; West 2006).

It is also suggested that adding human development components to conservation programs, and encouraging partnerships, was because conservation organizations had aspirations to secure greater budgets to feed a growing conservation bureaucracy, not only because of their concern for the plight of rural populations (Oates 1999: 46-58).

Locally run conservation initiatives in Amazonas and San Martin are increasing in number. They include the creation of protected areas, controls on hunting and deforestation, and offering efficient conservation solutions for many of the threats to species and habitat (Shanee et al. Accepted). Although small scale, low budget, locally run conservation projects are now common globally (Borrini-Feyerabend et 
al. 2004; Horwich et al. 2011; Pathak et al. 2004), the literature seldom describes them in detail or shows the rationales behind them (Fletcher 2010; Horwich and Lyon 2007; Horwich et al. 2011; Igoe and Brockington 2007). Exposure is even scarcer in the case of conservation programs where rural dwellers are not passive respondents to external conservation agents but are active proponents and executers of their own conservation initiatives. Moreover, conservation is often represented in social science and especially in political ecology literature as antagonistic and harmful to local populations, stressing the social conflicts resulting from local resistance to conservation projects. This creates a notion that there is an inherent, inevitable clash between local populations and conservation with very little academic attention to cases that suggest otherwise.

In answer to these gaps in the literature I employed a range of social science methods to record experiences gathered during my work in the departments of Amazonas and San Martin in Peru, from 20072013. I do not aim to determine or homogenize rural epistemologies, but I describe the range of ideas used by campesinos in Amazonas and San Martin to justify their own conservation initiatives. I do so in order to provide voices for people not often represented in academic conservation literature, and to encourage more academic attention towards locally run conservation initiatives.

\section{Methods}

I used ethnographic methods including interviews, questionnaires and participant observation, to determine justifications given by campesinos for conservation initiatives (LeCompte and Schensul 1999). I also recorded the views, ideologies and behaviour of campesinos and conservation agents towards biodiversity. For additional quantitative data, questionnaires were administrated to local leaders of the Ronda Campesina grassroots organization, and the Catholic and evangelical churches throughout rural Amazonas and San Martin (Schensul et al. 1999). Through direct contact with authorities in both regions and the central government, I gathered information about existing and proposed private and communal protected areas. Participant observation took place spread across several years to explore the views and behaviours of local conservation initiators, professionals who support these initiatives, and the interactions between them. The initiatives reviewed in this article are of communities, associations and individuals that identify themselves with campesino populations. All data and quotes were gathered in Spanish and were translated to English by the author.

The study took place throughout the departments of Amazonas and San Martin on the eastern slopes of the Andean Cordillera in northeastern Peru (Figure 1). The topography of these departments range from high mountain sierras to lowland rainforest. The geological formation of the Andean cordillera created a mosaic of steep slopes and peaks which restricted the movements of organisms, and leaves isolated varied habitats and climatic conditions that have encouraged the evolution of an extremely high number of endemic species (Young and León 1999). Combined, these departments have a human population of close to one million (INEI 2007). Both departments are active fronts of colonization and deforestation (INEI 2007; Shanee 2012a).

This work took place during my time as a co-director of the Yellow Tailed Woolly Monkey Project, run by UK NGO 'Neotropical Primate Conservation' (NPC). My personal engagement with conservation initiatives in the study area allowed for an intimate understanding of both degradation and conservation processes. It facilitated a more thorough validation of the data, since all discourses included here were triangulated with the actions they promoted and their effect on the ground. To reduce further bias related to my positionality as researcher and representative of a conservation organization, I have limited the use of results from formal interviews, as I found them generally more biased towards my work, and I rely here on informal communications and public meetings where people talked with peers and neighbors in my presence, rather than directly to me. In all stages of data collection and analysis I took into account that campesino populations are not homogenous and vary on many economic and ideological levels, therefore I include as many quotations as possible to allow different voices and actors to be directly introduced through this work.

\section{Results - rural campesino justification for conservation actions}

Small scale locally run conservation initiatives exist in Amazonas and San Martin and include the creation of 18 protected areas run by campesino groups, protecting 282,768 ha and seven more in the registration process totaling 53,570 ha (see Table 1 ). There are also hundreds of smaller and less quantified projects of reforestation and internal control of deforestation and hunting, giving partial protection to extensive areas (Shanee et al. Accepted).

For their participation and initiation of conservation efforts people suggested reasoning which could be categorized under both anthropocentric and ecocentric ideologies, as follows. 


\section{Ecocentric reasoning}

In the discourses of local conservation agents, they often stressed that the state and NGO employees work to protect nature for its intrinsic value, due to their higher education in the big cities or abroad, while local people only cooperate with conservation initiatives because of their anthropocentric interests, including economic incentives or environmental services. In a participatory meeting arranged by the Regional Environmental Authority of San Martin in March 2011, many national and international NGOs and regional government agents took part in order to define conservation goals for the region. The representative of the authority said: "We need to talk about the benefits of conservation to humans....We are the cherry in the cream, we have to write it in a way that will make sense to the Campesinos". In a private interview a representative of a national NGO told me "you can not expect them (campesinos) to conserve just because nature is beautiful, they are not like us".

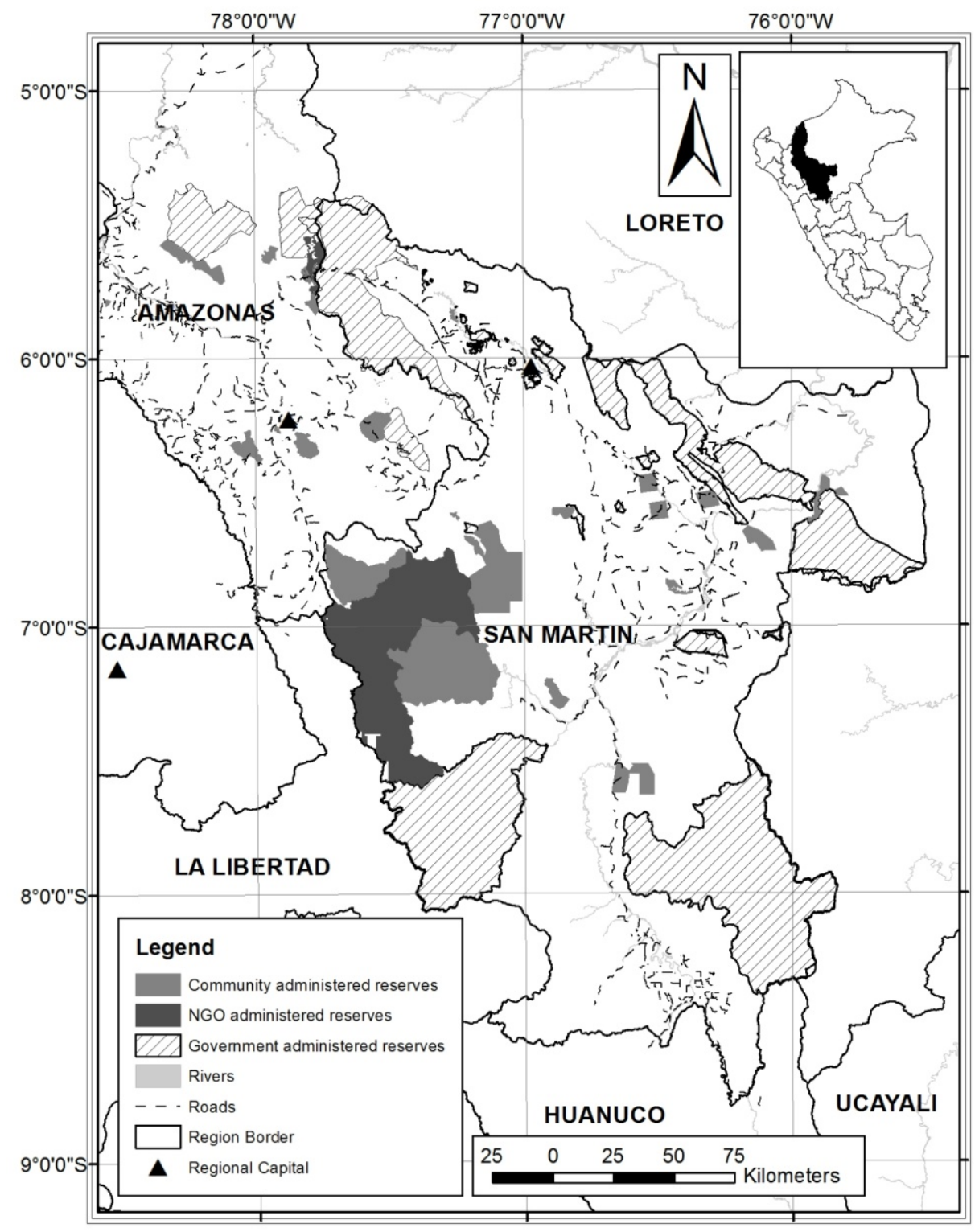

Figure 1: Study area in Peru. Source: author. 
The following justifications given by campesinos focus on nature's intrinsic value. In 2012 La Primavera Agricultural Producers Association (APALP) registered a Conservation Concession ${ }^{3}$ of 7,418 ha, in an area that they have informally protected since 1990 . One of the associations' founders commented in a personal interview:

I arrived here for the first time in 1988, and started to walk in the forests. Here I discovered virgin forests teeming with life. I was very sad to see it vanishing. I decided to find groups that would join with me to protect these places....We have a small group of people and we have a connection with an organization that is helping us to acquire the land permit for a Concession, and we are on the right track. I am very grateful and pleased.

In a later conversation, a woman from the same association added: "All we want is that the tapirs 4 and other big animals will come back". She also said that the squatter/owner of most of the land proposed for the reserve was recently offered 100,000 New Soles (about US\$ 35,000) for his land to be divided between new migrants for farming but he refused, although he knows that creating the reserve is unlikely to bring him any significant revenue.

A local farmer from the Yambrasbamba community said in an informal interview that his dream is to buy and conserve 300 ha of forested land behind his village, Santa Rosa, because there are groups of the Critically Endangered yellow tailed woolly monkey there (Oreonax flavicauda). The land was offered for sale, and he worried that other buyers would clear cut it. He heard the monkeys there recently, and found it beautiful. He was very worried about the future of these monkeys and wants them to stay near his house. In an informal interview, another resident of La Esperanza criticized the idea of protecting lands while allowing selective logging, an idea he was introduced to by an NGO promoting sustainable logging practices: "I don't agree that it will not disturb the monkeys because the loggers will have to cut trails and make noise and the animals will run away. My dream is a place where no one enters".

Some of the reasons given by people who had stopped hunting monkeys included: "because they are really beautiful"... "I was going to shoot it but felt sorry for it", and "because they don't do any harm to us".

Justifications also often concentrated on the religious and spiritual values of nature. In answers to written questionnaires given to 101 local Catholic and 96 Evangelist leaders, $94 \%(n=186)$ stated that they feel part of their job as religious leaders is to help promote environmental issues. They said they are doing so by instructing people to conserve the environment, stressing the spiritual and material importance of nature or demonstrating by personal example. The main promoters of two of the locally run reserves in the area, Pampa del Burro and Sun Angel's Gardens, are both local church leaders.

A Ronda leader said in a general meeting:

We have to defend the patria, the forests, the animals, the rivers; everything that we can see is the creation and we have to defend it. Life started in the water, the spirit of god was above the water. If there is no water there is no life. We have to defend it. Life and water ... We and our body are part of the environment ... When you kill animals you have to know that they are part of the creation; we are not allowed to kill the animals that give us life, as it is not part of the continuation of the liberating work of Christ.

The same leader instructed in another meeting:

You must punish every person that burns hillsides because he kills millions of lives; millions of micro organisms. It is a sin. Also the selling of animals, we cannot kill animals or sell them.

A farmer from Bagua told this story in a Ronda meeting:

My friend was working in his field when hunters came to his land. He chased them away and threatened to shoot them if they ever return. They asked him why he doesn't let them shoot the animals that are eating all of his crops. He said 'I work for myself, for my family and for the animals that god created'.

\footnotetext{
${ }^{3}$ In Peru there are two different kinds of non-government protected areas; one, on privately owned lands, such as titled family plots or community lands, can be registered as Private Conservation Areas for an unlimited time through application to the Ministry of the Environment. The other kind is on state owned land (not titled), which has to be registered with the Regional Government as a Concession for Conservation for up to 40 years, renewable.

${ }^{4}$ Tapirus terestres.
} 
An ad-lib conversation with a man from Guailulo community of Amazonas revealed: "people who hunt are the ones who still don't understand that animals are part of the creation made by the love of god. My church, evangelical, tells us that it is not allowed to kill wildlife".

\section{Anthropocentric reasoning a) Forest resources and sustainability}

The undertaking of many initiatives is rationalized as a way that tries to offset growing problems resulting from climate change and water scarcity. A representative of the Peruvian Society for Environmental Law (SPDA) in Amazonas believes that this is the main reason for the proliferation of private conservation initiatives in recent years. Sustainable resource use is heavily promoted in the discourses of conservation agents as strategies for sustainable/eco-friendly development, in the domains of subsistence consumption of water, the attraction of tourism and commercial exportation of commodities.

A leader of the Ronda Campesina said: "We will guard our forest and have sustainable agriculture and have progress for the future of our children". In one small project a family planted trees near a stream, a young woman introducing this work said: "this is because we know our reality; the water is disappearing. We feel obliged to plant."

Lack of fertile land and water in the areas where people have migrated from is often mentioned as a warning in campesino discourse. The president of La Primavera Agricultural Producers Association (APALP) explained to his neighbors why he wants to make a Conservation Concession:

We all remember why we came to live here; the land was barren and the water was scarce and polluted. Now we see the same happening here, there are only two hours of running water daily in Nuevo Chirimoto and La Union. ${ }^{3}$ We must change the way things are, so we can keep living here. We must conserve our forests.

The community of Corosha and the Association of Sustainable Development and Conservation Ricardo Palma have both registered reserves for the protection of water resources and small hydroelectric plants.

\section{Anthropocentric reasoning b) Economic reasoning}

NGOs in the area often promote economic reasons for conservation. Characteristic discourses in the area are "You cannot ask people to conserve on an empty stomach," ${ }^{6}$ or:

...conservation is just a bonus, the main thing is development, so everyone stands in line for conservation because who wouldn't like more money? It is business. Both the locals and the Regional Government are queuing; getting the communities interested is not a big deal.

In a participatory meeting arranged by the regional government of San Martin, the Director explained that the green economy, sustainable development and human health must predominate in conservation discourses proposed to local people: "We want to break the paradigm that conservation is not to touch. The most important thing is humans, no? The goal is human welfare. We shouldn't talk about 'conservation' because it can scare people."

It is possible to divide people's aspiration for economic gains from conservation oriented activities into two distinct categories. The first sees economic income as a method to sustain and expand the main goal of conservation. It is important to note that this reasoning can still be seen as ecocentric, if we consider the limited resources rural dwellers have available to invest in their own conservation projects, as well as the high costs of formal private conservation in Peru (Shanee et al. Accepted). The next examples belong to this category.

The Association of Farmers for the Conservation of the Forests of Simacache, explained in a meeting with the Regional Government of San Martin that they understand the responsibility involved in the management of a 51,000 ha Conservation Concession, especially as there are few members and with low income. Therefore, they look for alliances and funding sources that will help them cover the management costs: "We are not looking to get rich or even gain anything from protecting this area, we have enough income from our farms, but we will need more money to ensure that people don't enter Gran Simacache (the concession) to hunt or farm."

\footnotetext{
${ }^{5}$ Neighboring villages.

${ }^{6}$ A representative of the local NGO Ecoverde.

${ }^{7}$ Representative of the international NGO Nature and Culture International (NCI).
} 


\begin{tabular}{|c|c|c|c|c|c|c|}
\hline Region & Name of area & Type of area & Registered & $\begin{array}{l}\text { year of } \\
\text { registry }\end{array}$ & Applicant & Hectares \\
\hline \multirow{10}{*}{ Amazonas } & Tilacancha & ACP & Registered & 2010 & Campesino community & 6,800 \\
\hline & Copallin & $\mathrm{ACP}$ & Registered & 2011 & Campesino community & 11,549 \\
\hline & Hierba Buena-Allpayacu & $\mathrm{ACP}$ & Registered & 2011 & Campesino community & 2,282 \\
\hline & Milpuj-La Heredad & $\mathrm{ACP}$ & Registered & 2011 & Local individual & 16 \\
\hline & Huaylla Belen-Colcamar & $\mathrm{ACP}$ & Registered & 2011 & Campesino community & 6,338 \\
\hline & Iguahuana- Dry Forests of Delta & CC & Registered & 2012 & Local individual & 423 \\
\hline & Los Chilchos & ACP & Registered & 2012 & Campesino community & 46,378 \\
\hline & Palm Forest Taulia Molinopampa & ACP & Registered & 2012 & Campesino community & 10,920 \\
\hline & Pampa del Burro & ACP & Registered & 2013 & Campesino community & 2,776 \\
\hline & Berlin & ACP & Registered & 2013 & Local individual & 59 \\
\hline \multicolumn{6}{|l|}{ Total } & 87,541 \\
\hline \multirow{15}{*}{ San Martin } & Paraiso de Yurilamas & CC & Registered & 2005 & Association & 6,966 \\
\hline & El Breo & $\mathrm{CC}$ & Registered & 2010 & Association & 113,826 \\
\hline & Ojos de Agua & $\mathrm{CC}$ & Registered & 2010 & Association & 2,413 \\
\hline & El Gran Simacache & $\mathrm{CC}$ & Registred & 2012 & Association & 51,269 \\
\hline & San Angel's gardens & $\mathrm{CC}$ & Registered & 2012 & Association & 7,418 \\
\hline & Shitariyacu & $\mathrm{CC}$ & Registered & 2012 & Association & 1,591 \\
\hline & Tres Quebradas & $\mathrm{CC}$ & Registered & 2012 & Association & 4,176 \\
\hline & Sacha Runa & $\mathrm{CC}$ & Registered & 2012 & Association & 7,568 \\
\hline & Bosque el Quinillal & $\mathrm{CC}$ & In process & & Association & 15,900 \\
\hline & Bosques de Pailayco & $\mathrm{CC}$ & In process & & Association & 808 \\
\hline & Cuñumbuza & $\mathrm{CC}$ & In process & & Association & 4,500 \\
\hline & Huicungal & CC & In proccess & & Association & 1,696 \\
\hline & Porvenir - Pelejo & $\mathrm{CC}$ & In process & & Association & 7,758 \\
\hline & Valle del Biavo & $\mathrm{CC}$ & In process & & Association & 12,308 \\
\hline & Yacu Kawsanapa & CC & In process & & Association & 10,600 \\
\hline \multicolumn{6}{|l|}{ Total } & 248,797 \\
\hline
\end{tabular}

Table 1: Current and proposed protected areas run by campesino groups and individuals in Amazonas and San Martin (2013) 
The head of the Yambrasbamba tourism committee explained to the community assembly:

Do not kill animals. You can only kill an animal once and sell it once. Tourists will pay all the time to see these animals.....When 'gringos' come and see garbage they will not come back. If they see an animal dead or captured they will not return. This should stop immediately. It is forbidden to hunt animals, it is forbidden to burn forests.

There are other examples of people interested in conservation as a way to gain income. The president of Yambrasbamba community explained in an interview that he believes that creating the communally run Private Protected Area, Pampa del Burro, is only the first step in conserving forests in his community. It will open doors for the community to collaborate with different institutions helping with carbon sequestration payments, tourism, eco-friendly agriculture etc. "...the idea is that our own people see that our natural resources can generate income for us without degrading them."

When a man in Nuevo Chirimoto interested in creating a private Protected Area on 500 ha of his land understood that there would be no direct payment involved and economic benefits were only possible in the long term, he quickly lost interest. In many cases people offer lands for sale to conservation NGOs working in the area, hoping for quick financial returns.

A woman from the 'Triunfo' Association explained during a meeting that the land they owned was unsuitable for agriculture, but as there were endemic species on the land they decided that conservation and ecotourism would be the best use for the area. However, this Association decided not to pursue legal protection of their land, possibly because they understood that income is not guaranteed.

A 2010 study from San Martin by the NGO Group for the Analysis of Development (GRADE) asked what the smallest single payment a rural dweller would be willing to receive for conserving one ha forever would be. Some 55\% answered 0-3000 New Soles ( US\$ 1,000); however, most people living near the Alto Mayo Protected Forest asked for a minimum of 15,000 New Soles ( US\$5,000). ${ }^{8}$ The explanation given by GRADE is that these people have heard of the Reducing Emissions from Deforestation and Forest Degradation (REDD) payment schemes run by Conservation International. The expectation of economic gain created by this project has also attracted immigration from other areas into the Protected Forest and its surrounds.

\section{Anthropocentric reasoning c) Class/social struggle reasoning for conservation}

Conservation is sometimes used as part of a social struggle, and not purely for environmental reasons. In this context, mainstream conservation and especially its economic incentives are often criticized by campesinos.

One of the leaders of the Ronda Campesina said in the organization's general assembly:

Making conservation concessions will help us fight the mining companies because they will understand that we don't only oppose mining, we have our own positive ideas of conservation and development.

Another Ronda member said in the same meeting "We cannot criticize the mine and then burn all the forests."

Protected areas are also considered as a way in which communities can organize their land use and even get help from outside agents in doing so. The President of Yambrasbamba Community explains: "one of the ideas of conserving this area is to stop migrants that come from other regions and take possession of our communal lands". It is also a way in which they hope to receive positive attention from state authorities. A party arranged by the villagers of Delta to celebrate the launch of the Conservation Concession Iguahuana, included the participation of municipal and regional government agents. Many of the local participants expressed their contentment with the authorities' presence and said that this is one of the first times such "important people" had visited this village, which was "abandoned by the state." They expressed the hope that now, after the village had demonstrated its good practices by initiating conservation, the government will start taking notice and provide them with what they deserve as citizens, such as potable water, drainage systems and improved road access.

The presence of conservation agents who support campesinos initiatives is largely seen as positive; in a personal interview, a Ronda leader said:

${ }^{8}$ GRADE unpublished, presented in a REDD Meeting in Moyobamba 29/3/2011. 
In Amazonas we did not have conservation organizations and we felt like orphans.... We decided in the Ronda that we will cooperate with any conservation organizations to fight for the protection of life. ${ }^{9}$ The campesino has to defend the environment for agriculture. From NGOs we learnt of environmental issues and it helped us to confront the great dangers of environmental contamination. We hope that with talks and workshops we can elevate the level of theory and culture of the campesino to better defend the environment.

Conservation agents are very often criticized, however, for their inefficiency. A Ronda leader in a participatory meeting of NGOs and the regional government of Amazonas said:

We have no patience for theory, we are only interested in practicality...the Ronda has to coordinate with environmental organizations but I don't trust them. There are people that think that they can do conservation from the office. There are many organizations here .... And they all aim for the protection of the environment, but what is really happening? What are they doing? We have to start acting. For example the Ronda is more practical; we have already conserved Hocicon, La Primavera, Asucion Goncha and Delta. ${ }^{10}$ Sometimes without talking one can do a lot of things, that is what we as Ronda members like to do, we go from village to village, we lead by example. Unfortunately it is not recognized by the state. I don't want this to be the last time that you invite us, we should always coordinate. But for action, for working, not for theorizing.

It can be understood, therefore, that creating reserves and doing conservation is a way in which campesinos show their superiority in conservation to what they see as inefficient state mechanisms and projects. A local teacher and a conservation promoter said during a group meeting: "we will win...the Regional Government will learn from us, we will make reserves everywhere."

A representative of the San Martin grassroots association Choba-Choba said in a meeting organized by the San Martin regional government: "there are many people that want to conserve, because of their culture and as part of the campesino movement. They are worried about climate change. They don't conserve for money but against money." In other words, he finds that campesinos perceive climate change to be a result of the current economic system. For them, receiving monetary incentives for forest conservation would be the same as cooperating with this same system that they oppose. Moreover, the president of the Ronda Campesina in Amazonas advised people that when an NGO comes and offers money straight away, it should not be accepted.

Perhaps the strongest discourse related to this category was offered by one of the national leaders of the Ronda Campesina in the organizations general assembly: "Defence of the environment is part of the class struggle....We are the people that defend the things that have no economic value".

\section{Discussion}

The justifications given by campesinos for their own conservation actions can be categorized into ecocentric and anthropocentric views, although these are categories used by scholars in the developed world (Cafaro 2001; Paterson 2006). The groups initiating conservation projects in Amazonas and San Martin have given a range of rationales that combine environmental, social and economic reasoning. Reflections on religious and moral principles often result in the notion that nature has an intrinsic right to exist and local discourses highlight its aesthetic values. Environmental campaigning by external conservation agencies adds justifications that are inclined towards anthropocentric reasoning. When they are told about its international uniqueness, Campesinos begin to recognize local nature as a source of social capital and as grounds for pride. Their experiences as a migrant population that suffered environmental problems give them a personal understanding of the dangers of degradation.

The aspiration for sustainability is heavily promoted by conservation agents and it motivates many land protection initiatives, as this study shows. The concept of sustainability is complex, however, and varies between different thinkers (Hulme and Murphree 2001). The Millennium Ecosystem Assessment (2005) asserts that current human consumption far exceeds the earth's resources, with 60\% of ecosystem services already being degraded or used unsustainably. In this sense, sustainable development is criticized for being constrained by the current economic system (Haque 1999). More drastic criticisms of sustainable development perceive it as a market-friendly concept, reinforcing and enabling the inherently unsustainable ideology that market forces are the best way to conserve environmental resources (Breunig 2006; Büscher 2008; Sklair 2001). Peru is one of the countries facing the highest risk of climate change with vulnerable rural areas (Brooks and Adger 2003; UNFCCC 2007). Tropical montane cloud forests are known to be

\footnotetext{
${ }^{9}$ Nature is often referred to as a source of life and a basic necessity for human existence.

${ }^{10}$ Names of groups/villages that started conservation projects.
} 
extremely vulnerable to global and local climate changes (Bubb et al. 2004; Markham 1998; Still et al. 1999). Protection of land, therefore, might not guarantee the long-term sustainability of biodiversity, water and other environmental services; especially in smaller conservation areas.

The economic value of forests, promoted by most NGOs and governments, is locally understood. Many campesinos, suffering from both economic and environmental pressures, find conservation to be an opportunity to combine what they perceive as morally right and what is promised to be economically beneficial. In many ways, this is a win-win conservation concept promoted by global and local conservation agents but also visible 'on the ground.' In northern Peru conservation schemes depend on external markets and grants. But payments for environmental services (PES), REDD, ecotourism and integrated conservation and development programs (ICDPs) are still in their preliminary stages. It is too early to demonstrate that these schemes can be economically and culturally beneficial to campesino populations. Nevertheless, experience from the area suggest that REDD and REDD+ projects and their prospects have hindered some community based/grassroots conservation initiatives (Shanee 2012a; Shanee et al. Accepted). Moreover, this article shows that opportunistic reactions to such financing mechanisms exist where the expectations attract people seeking a quick profit. A growing body of academic literature presents many theoretical and practical contradictions in the assumption that conservation can be achieved by giving nature a market value (Arsel and Büscher 2012; Bhusal 2009; Büscher and Arsel 2012; Corbera et al. 2007a; Corbera et al. 2007b; Fairhead et al. 2012; Landell-Mills and Porras 2002; MacDonald 2010; McAfee 2012; Rosa et al. 2003; Sullivan 2009, 2010; Vaccaro et al. 2013). These contradictions are ignored or dismissed by the discourses of most conservation agents in the area, mainly international and national ones, that strongly promote economic justifications.

Although earlier legal documents required that the master plan of each Private Conservation Area will divide an area between 'intangible', 'limited use', and 'direct use' zones, a new Presidential Resolution from 2010 does not permit designating intangible zones (where there are only scientific investigations and ecotourism; all direct use of resources is prohibited) inside these areas, leaving only 'limited use' and 'multiple use' zones. It can be argued that this new legalization illustrates the government's view of private conservation initiatives as an economic opportunity, rather than as nature conservation per se.

A statement by the Ronda Campesina leader, "We are the people that defend the things that have no economic value" is of particular significance as it points to a fundamental clash between local and neoliberal philosophies. According to neoliberal economic policy, nature is intended to acquire economic value and conservation interventions building on neoliberal theory claim that local people will only respond to economic benefits. This statement suggests that with the expansion of neoliberal initiatives the physical and moral space for Ronda conservation initiatives will shrink. On the other hand, some kind of outside financing source is essential for the creation and maintenance of many such initiatives, especially the formal private protected areas, which legally require a substantial economic investment, generally unavailable to rural campesinos (Shanee et al. Accepted). Moreover, it can be assumed that the association of conservation initiatives with economic gains is used by the government as a justification for the high economic investment they place as a condition for the formalization of these initiatives. This is again a bias against local philosophies described in the article, towards economic rationalization.

Left wing and revolutionary discourses retransmitted through the Ronda Campesina appear to stimulate interest in conservation, reflected in the number of projects they assist. They present conservation initiatives as an innovative approach for campesinos to gain self esteem, social power and to prove their moral superiority over what they see as corrupt or at least inefficient systems of governance. It can also be considered as a subtle form of rebellion against the state. On the other hand, the example from Delta shows that conservation initiatives are also used to attract recognition and aid from an 'absent' state.

Local people's ability to initiate and manage their own conservation projects is a novel achievement in Northern Peru's campesino populations. Private protected areas are acknowledged at the national level. On many occasions there is pride associated the creation of reserves, and a sense of inclusion, social power and morality, by doing the 'right thing'. This can lead to what Robert Horwich defines as an important aspect of grassroots conservation, the 'contagion effect', where success and pride of one local group stimulates similar conservation initiatives in others (Horwich et al. 2010; Horwich et al. 2011; Horwich et al. 2012). Indeed conservation initiatives are spreading quickly throughout Northeastern Peru (Shanee et al. Accepted).

According to a representative of the Peruvian Association for Nature Conservation (APECO), the reasons for the growing interest shown by campesino communities in conservation vary between both ecocentric and anthropocentric categories. She mentioned the main reason she encountered during her many years as a conservation practitioner in Northern Peru were:

a) prestige; ethics and aesthetic views of wildlife and forests;

b) the practical need for healthy ecosystems to provide environmental services for agriculture;

c) the perception of economic benefits from tourism and payments for ecological services. 
She adds that these same reasons have existed for many years. Recently, however, there are many more conservation opportunities and people are much more aware of them due to environmental education, newly available media emphasizing environmental problems, and personal experience of forest loss and its consequences.

Ecocentric justifications are used by some conservation agents. They are used to emphasize their own moral and cultural superiority. This overlooks ecocentric rationalities that come from rural people and which are used as theoretical validation for 'fortress conservation' on one hand or neoliberal conservation approaches on the other, both excluding rural people (Kopnina 2012b; Kopnina 2012a; Wilshusen et al. 2002). For different reasons, academics also criticize anthropologists and theoreticians of conservation for looking for the 'conservationist within' rural people, reinventing the 'noble savage' with inherent ecological moral status (Brosius 1997; Brosius et al. 1998; Inglehart 1995; Nadasdy 2005; Waitt 1999). But studies show there are not clear positive correlations between national or personal economic well-being and environmental concern (Brechin and Kempton 1994; Dunlap and Mertig 1995; Dunlap and York 2008). Indeed, in Peru, the bureaucratic processes needed for the creation of private land protection schemes require high economic investment and expertise, hindering campesinos' own conservation initiatives (Shanee 2012a; Shanee et al. Accepted). Furthermore, it can be argued that the exclusionary processes of conservation application actually lower campesinos' participation in conservation schemes and reinforce local and international discourse of campesinos' apathy to nature, contributing to further exclusion.

Butler and Acott (2007) found that ideas of nature's intrinsic value are favored by representatives of most conservation organizations in England. Nevertheless, the policies of these same organizations rarely represent such ideas. Campagna and Fernandez (2007) compared environmental organizations' visions and missions, showed that nature was largely portrayed as a resource and they concentrated on responding to the local population's economic needs, in order to attract donor audiences. Therefore, to justify such organizations' strategic choices within Amazonas and San Martin, the same discourses presenting rural campesinos as immoral forest destroyers are employed to persuade the public that campesinos would only change their actions in exchange for economic incentives. Studies have shown that such anthropocentric orientations are less likely to induce actions of actual environment protection than ecocentric ones (Gagnon Thompson and Barton 1994; Kortenkamp and Moore 2001). Again, NGOs in Northeastern Peru that encourage anthropocentric rationales conservation, possibly reduce the potential for local participation in conservation.

\section{Conclusions and recommendations}

This article analysed ethnographic data from the Tropical Andes Hotspot of Northeastern Peru, collected during a period of increasing environmental threats, but also, a growth in local conservation initiatives. Numerous studies and theoretical works have sought to understand the effects of recent conservation interventions on nature and rural people, the connections between rural people and their environment, and the connections between rural people and neighboring conservation efforts. There is also a growing body of literature concentrating on the link between neoliberal philosophies and conservation. These are innovative contemporary attempts to rationalize the frequent failure of conservation agencies in achieving their declared goals. Despite these insights, there has been very little attempt to describe rural grassroots efforts to conserve their own environment. Furthermore there is a lack of overarching attempts to bring these areas of research together and understand the interactions between external conservation agents and local conservation initiatives.

My results show that campesino justifications for conservation actions are varied and the majority contradict the epistemic view in mainstream conservation that promote economic benefits as the only way to attract local cooperation. Campesinos do embrace philosophies of nature's intrinsic value and are certainly not 'scared' by the concept of conservation. Moreover, they criticize mainstream conservation agents for inefficiency and inadequate methods and ideologies.

Social scientists and political ecologists often critique conservation, especially what they describe as 'fortress conservation', for the social conflicts it creates and its inherent discrimination towards local people (Brockington 2002; Hutton et al. 2005; Siurua 2006; Vaccaro et al. 2013). This study suggests, however, that local people are putting effort into setting up and protecting 'intangible' conservation areas in order to protect nature. Although they often do not agree with the way conservation is administrated by the state or by outside conservation agencies, they do initiate parallel projects, following similar objectives and justifications. Therefore, I suggest that the conflict between local people and conservation projects is not related to the fundamental nature of conservation, rather it is the result of the way conservation is administrated, resulting in antagonism by local people towards the institutions that administrate it.

I call on academics anthropologists and scholars of conservation to augment their work describing and assessing the shortfalls and successes of local initiatives over the long term. With proper feedback to the initiating groups, this could help them greatly improve their interventions. Publishing in academic and popular journals will inform conservation practitioners and the general public about the potential of locallyrun conservation, a potential that might be deliberately obscured by mainstream conservation institutions. A 
more informed public could provide more funding to small, locally run projects as well as encouraging highly biodiverse countries to simplify the conservation policy process to give local people equal opportunities to lead conservation initiatives and projects themselves.

In addition, in Northeastern Peru churches are a strong force, and various denominations show an interest in incorporating conservation messages into their work. Campesinos adopt these ethics and incorporate them into their conservation discourses and actions. I support Bhagwat et al.'s (2011) recommendation to investigate the possibilities for collaborations between conservation agents and religious leaders as an important conservation opportunity.

The article challenges the mainstream conservation ideologies promoted locally and internationally. It shows that for poor, local populations, conservation is not a 'dirty word.' Many rural people in Northeastern Peru found nature and biodiversity conservation attractive to their intrinsic, social, aesthetic and moral values, as well as being a measure to ensure their own future. In most cases the prospect of economic benefits was perceived as a welcome, but secondary, outcome and occasionally even as a hindrance. The study challenges conservation practitioners to be far more attentive and responsive to the requests and requirements of local communities, providing them with real opportunities to conserve their own environment.

\section{References}

Adams, W.M. 2004. Against extinction: the history of conservation. London: Earthscan.

Adams, W.M. and Hulme, D. 2001. If community conservation is the answer in Africa, what is the question? Oryx 35 (3): 193-200.

Agrawal, A. and Redford, K. 2006. Poverty, development, and biodiversity conservation: shooting in the dark? WCS Working Papers. Wildlife Conservation Society.

Arsel, M. and Buscher, B. 2012. Nature Inc.: changes and continuities in neoliberal conservation and market based environmental policy. Development and Change 43 (1): 53-78.

Barrett, C.B. and Arcese, P. 1995. Are Integrated Conservation-Development Projects (ICDPs) sustainable? On the conservation of large mammals in sub-Saharan Africa. World Development 23 (7):10731084.

Bebbington, A.J. 1990. Farmer knowledge, institutional resources and sustainable agricultural strategies: a case study from the eastern slopes of the Peruvian Andes. Bulletin of Latin American Research 9 (2): 203-228.

Bebbington, A.J. and Bury, J.T. 2009. Institutional challenges for mining and sustainability in Peru. Proceedings of the National Academy of Sciences, 106 (41): 296-301

Bhagwat, S.A., Dudley, N., and Harrop, S.R. 2011. Religious following in biodiversity hotspots: challenges and opportunities for conservation and development. Conservation Letters 4 (3): 234-240.

Bhusal, Y. 2009. Problems and prospects of REDD in community based forest management system. The Greenery-a Journal of Environment and Biodiversity, 7(1): 46-52.

Borrini-Feyerabend, G., Pimbert, M., Farvar, J.C. Taghi, Kothari, A., and Renard, Y. 2004. Sharing power: learning by doing in co-management of natural resources throughout the world. Cenesta, Tehran: IIED and IUCN/CEESP/CMWG.

Bóveda-Penalba, A., Vermeer, J., Rodrigo, F., and Guerra-Vásquez, F. 2009. Preliminary report on the distribution of (Callicebus oenanthe) on the eastern feet of the Andes. International Journal of Primatology 30 (3): 467-480.

Brechin, S.R. and Kempton, W. 1994. Global environmentalism: a challenge to the postmaterialism thesis? Social Science Quarterly 75 (2): 245-269.

Breunig, L.A. 2006. Conservation in context: establishing natural protected areas during Mexico's neoliberal reformation. PhD dissertation. Tucson: University of Arizona.

Brockington, D. 2002. Fortress conservation: the preservation of the Mkomazi Game Reserve, Tanzania. Oxford: James Currey.

Brooks, N. and Adger, W.N. 2003. Country level risk measures of climate-related natural disasters and implications for adaptation to climate change. Working Paper 26. Tyndall Centre for Climate Change Research.

Brosius, J.P. 1997. Endangered forest, endangered people: environmentalist representations of indigenous knowledge. Human Ecology 25 (1): 47-69. Reprint 2006

Brosius, J.P., Tesing, A.L., and Zerner, C. 1998. Representing communities: histories and politics of community-based natural resource management. Society and Natural Resources 11 (2): 157 - 168.

Brown, K. 2002. Innovations for conservation and development. The Geographical Journal 168 (1): 6-17.

Bubb, P., May, I., Miles, L., and Sayer, J. 2004. Cloud forest agenda. UNEP-WCMC Biodiversity Series No. 20. Cambridge: UNEP-WCMC. 
Bury, J. 2005. Mining mountains: neoliberalism, land tenure, livelihoods, and the new Peruvian mining industry in Cajamarca. Environment and Planning A 37 (2): 221-239.

Bury, J. 2007. Mining migrants: transnational mining and migration patterns in the Peruvian Andes. The Professional Geographer 59 (3): 378-389.

Büscher, B. 2008. Conservation, neoliberalism, and social science: a critical reflection on the SCB 2007 Annual Meeting in South Africa. Conservation Biology 22 (2): 229-231.

Büscher, B. and Whande, W. 2007. Whims of the winds of time? Emerging trends in biodiversity conservation and protected area management. Conservation and Society 5 (1): 22-43.

Büscher, B. and Arsel, M. 2012. Introduction: neoliberal conservation, uneven geographical development and the dynamics of contemporary capitalism. Tijdschrift voor economische en sociale geografie, 103 (2): 129-135.

Butler, W.F. and Acott, T.G. 2007. An inquiry concerning the acceptance of intrinsic value theories of nature. Environmental Values 16 (2): 149-168.

Cafaro, P. 2001. Thoreau, Leopold, and Carson: toward an environmental virtue ethics. Environmental Ethics 23 (1): 3-18.

Campagna, C. and Fernandez, T. 2007. A comparative analysis of the vision and mission statements of international environmental organisations. Environmental Values 16 (3): 369-398.

CBDS 2001. Handbook of the Convention on Biological Diversity. Secretariat of the Convention on Biological Diversity. London: Earthscan.

Cernea, M.M. and Schmidt-Soltau, K. 2006. Poverty risks and national parks: policy issues in conservation and resettlement. World Development 34 (10): 1808-1830.

Corbera, E., Brown, K., and Adger, W.N. 2007a. The equity and legitimacy of markets for ecosystem services. Development and Change 38 (4): 587-613.

Corbera, E., Kosoy, N., and M. Martìnez Tuna. 2007b. Equity implications of marketing ecosystem services in protected areas and rural communities: case studies from Meso-America. Global Environmental Change 17 (3): 365-380.

Dunlap, R.E. and Mertig, A.G. 1995. Global concern for the environment: is affluence a prerequisite? Journal of Social Issues 51 (4): 121-137.

Dunlap, R.E. and York, R. 2008. The globalization of environmental concern and the limits of the postmaterialist values explanation: evidence from four multinational surveys. The Sociological Quarterly 49 (3): 529-563.

Durand, L. and Vázquez, L.B. 2010. Biodiversity conservation discourses. A case study on scientists and government authorities in Sierra de Huautla Biosphere Reserve, Mexico. Land Use Policy 28: 7682.

Fairhead, J., Leach, M., and Scoones, I. 2012. Green grabbing: a new appropriation of nature? Journal of Peasant Studies 39 (2): 237-261.

Fletcher, R. 2010. Neoliberal environmentality: towards a poststructuralist political ecology of the conservation debate. Conservation and Society 8 (3): 171-181.

Gagnon Thompson, S.C. and Barton, M.A. 1994. Ecocentric and anthropocentric attitudes toward the environment. Journal of Environmental Psychology 14 (2): 149-157.

Haque, M.S. 1999. The fate of sustainable development under neo-liberal regimes in developing countries. International Political Science Review 20 (2): 197-218.

Hayden, C. 2003. When nature goes public: the making and unmaking of bioprospecting in Mexico. Princeton University Press.

Horwich, R., Lyon, J., and Bose, A. 2011. What Belize can teach us about grassroots conservation. Solutions 2 (3).

Horwich, R.H. and Lyon, J. 2007. Community conservation: practitioners' answer to critics. Oryx, 41 (03): 376-385.

Horwich, R.H., Lyon, J., Bose, A., and Jones, C.B. 2012. Preserving biodiversity and ecosystems: catalyzing conservation contagion. In P. Moutinho (ed.), Deforestation around the world. InTech Rijeky, Croatia: intechopen.com. Pp 283-318.

Horwich, R.H., Islari, R., Bose, A., Dey, B., Moshahary, M., Dey, N.K., Das, R., and Lyon, J. 2010. Community protection of the Manas Biosphere Reserve in Assam, India, and the Endangered golden langur (Trachypithecus geei). Oryx 44 (02): 252-260.

Hulme, D. and Murphree, M. 2001. Community conservation in Africa: an introduction. In D. Hulme and M. Murphree (eds.) African wildlife and livelihoods. The promise \& performance of community conservation Oxford: James Currey.

Hutton, J., Adams, W.M., and Murombedzi, J.C. 2005. Back to the barriers? Changing narratives in biodiversity conservation. Forum for Development Studies 32 (2): 341-370. 
Igoe, J. and Brockington, D. 2007. Neoliberal conservation: a brief introduction. Conservation and Society 5 (4): 432-449.

INEI. 2007. Resultados definitivos. Censos Nacionales 2007. Peru: Instituto Nacional de Estadística e Informática.

Inglehart, R. 1995. Public support for environmental protection: objective problems and subjective values in 43 societies. PS: Political Science and Politics 28 (1): 57-72.

Jeanrenaud, S. 1998. Can the leopard change its spots? Exploring people-oriented conservation in WWF. University of East Anglia. related

Kellert, S.R., Mehta, J.N., Ebbin, S.A., and Lichtenfeld, L.L. 2000. Community natural resource management: promise, rhetoric, and reality. Society and Natural Resources 13 (8): 705-715.

Kiss, A. 2004. Making biodiversity conservation a land-use priority. In T.O. McShane and M.P. Wells (eds.) Getting biodiversity projects to work. New York: Columbia University Press. Pp 98-123.

Kopnina, H. 2012a. Re-examining culture/conservation conflict: the view of anthropology of conservation through the lens of environmental ethics. Journal of Integrative Environmental Sciences 9 (1): 9-25.

Kopnina, H. 2012b. Education for sustainable development (ESD): the turn away from 'environment' in environmental education? Environmental Education Research 18 (5): 699-717.

Kortenkamp, K.V. and Moore, C.F. 2001. Ecocentrism and anthropocentrism: moral reasoning about ecological commons dilemmas. Journal of Environmental Psychology 21 (3): 261-272.

Landell-Mills, N. and Porras, I.T. 2002. Silver bullet or fools' gold? A global review of markets for forest environmental services and their impact on the poor. London: International Institute for Environment and Development.

LeCompte, M.D. and Schensul, J.J. 1999. Designing and conducting ethnographic research. London: AltaMira Press.

Leopold, A. 1970. A Sand County almanac: with essays on conservation from Round River. New York: Ballantine.

Loker, W.M. 1996. "Campesinos" and the crisis of modernization in Latin America. Journal of Political Ecology 3: 69-88.

MacDonald, K.I. 2010. The devil is in the (bio) diversity: Private sector "engagement" and the restructuring of biodiversity conservation. Antipode 42 (3): 513-550.

Markham, A. 1998. Potential impacts of climate change on tropical forest ecosystems. Climatic Change 39 (2): 141-143.

McAfee, K. 2012. The contradictory logic of global ecosystem services markets. Development and Change 43 (1): 105-131.

McShane, T.O. and Wells, M.P. (eds.) 2004. Getting biodiversity projects to work. New York: Columbia University Press.

Millennium Ecosystem Assessment 2005. Ecosystems and human well-being: current state and trends. New York: Island Press.

Mittermeier, R.A., Wallis, J., Rylands, A.B., Ganzhorn, J.U., Oates, J.F., Williamson, E.A., Palacios, E., Heymann, E.W., Kierulff, M.C.M., Yongcheng, L., Supriatna, J., and Roos, C. 2009. primates in peril: the world's 25 most endangered primates 2008-2010. Arlington, VA: IUCN/SSC Primate Specialist Group (PSG), International Primatological Society (IPS), and Conservation International (CI).

Mittermeier, R.A., Schwitzer, C., Rylands, A.B., Taylor, L.A., Chiozza, Williamson, E.A., and Wallis, J. (eds.) 2012. Primates in peril: the world's 25 most endangered primates 2012-2014. Bristol: IUCN/SSC Primate Specialist Group (PSG), International Primatological Society (IPS), Conservation International (CI), and Bristol Conservation and Science Foundation.

Myers, N. 2003. Biodiversity hotspots revisited. BioScience 53 (10): 916-917.

Myers, N., Mittermeier, R.A., Mittermeier, C.G., da Fonseca, G.A.B., and Kent, J. 2000. Biodiversity hotspots for conservation priorities. Nature 403 (6772): 853-858.

Nadasdy, P. 2005. Transcending the debate over the ecologically noble Indian: Indigenous peoples and environmentalism. Ethnohistory 52 (2): 291-331.

Nugent, S. 1993. Amazonian caboclo society: an essay on invisibility and peasant economy. Oxford: Berg.

Nygren, A. 2000. Development discourses and peasant-forest relations: natural resource utilization as social process. Development and Change 30: 11-34.

O'Dea, N., Araújo, M. B., and Whittaker, R. J. 2006. How well do Important Bird Areas represent species and minimize conservation conflict in the tropical Andes? Diversity and Distributions 12 (2): 205214.

Oates, J.F. 1999. Myth and reality in the rain forest: how conservation strategies are failing in West Africa Berkeley: University of California Press. 
Palmer, C. 2003. An overview of environmental ethics. In A. Light and H. Rolston (eds.), Environmental ethics: an anthology. Oxford: Blackwell. Pp 15-37.

Paterson, B. 2006. Ethics for wildlife conservation: overcoming the human-nature dualism. Bioscience 56 (2): $144-150$.

Pathak, N., Bhatt, S., Balasinorwala, T., Kothari, A., and Borrini-Feyerabend, G. 2004. Community conserved areas: a bold frontier for conservation. Tehran: TILCEPA/IUCN, CENESTA, CMWG and WAMIP.

PROCLIM/CONAM. 2005. Informe del Proyecto PROCLIM - CONAM. Lima: INRENA.

Reategui, F. and Martinez, P. 2007. Forestal. Zonificación ecológica económica del Departamento de Amazonas. Chachapoyas: Gobierno Regional de Amazonas \& IIAP.

Rodríguez, L.O. and Young, K.R. 2000. Biological diversity of Peru: determining priority areas for conservation. Ambio 29 (6): 329-337.

Rosa, H., Kandel, S., and Dimas, L. 2003. Compensation for environmental services and rural communities. Lessons from the Americas and key issues for strengthening community strategies. San Salvador: PRISMA.

Schensul, S.J., Schensul, J.J., and LeCompte, M.D. 1999. Essential ethnographic methods. London: Altamira Press.

Schulenberg, T. S., Stotz, D. F., Lane, D. E., O'Neill, J. P., and Parker, T. A. 2010. Birds of Peru. New Jersey: Princeton University Press.

Shanee, N. 2012a. The dynamics of threats and conservation efforts for the Tropical Andes Hotspot in Amazonas and San Martin, Peru. PhD dissertation. University of Kent. abstract

Shanee, N. 2012b. Trends in local wildlife hunting, trade and control in the Tropical Andes Biodiversity Hotspot, northeastern Peru. Endangered Species Research 19: 177-186.

Shanee, N., Shanee, S., and Horwich, R.H. Accepted. Locally run conservation initiatives in northeastern Peru and their effectiveness as conservation methods. Oryx exerpt, 2013

Shanee, S. 2011. Distribution survey and threat assessment of the yellow-tailed woolly monkey (Oreonax flavicauda; Humboldt 1812), Northeastern Peru. International Journal of Primatology, 32 (3): 691707.

Shanee, S., Tello-Alvarado, J. C., Vermeer, J., and Boveda-Penalba, A. J. 2013. GIS risk assessment and GAP analysis for the Andean titi monkey (Callicebus oenanthe). Primate Conservation 26(1): 1723.

Siurua, H. 2006. Nature above people: Rolston and "fortress" conservation in the South. Ethics and the Environment. 11 (1): 71-96.

Sklair, L. 2001. The transnational capitalist class. Oxford: Wiley-Blackwell.

Stattersfield, A., Crosby, M., Long, A., and Wege, D. 1998. Endemic Bird Areas of the world: priorities for biodiversity conservation. Washington DC: Smithsonian Books.

Still, C.J., Foster, P.N., and Schnieder, S.H. 1999. Simulating the effects of climate change on tropical montane cloud forests. Nature 398: 608-610.

Sullivan, S. 2009. Green capitalism, and the cultural poverty of constructing nature as service provider. Radical Anthropology 3: 18-27.

Sullivan, S. 2010. 'Ecosystem service commodities' - a new imperial ecology? Implications for animist immanent ecologies, with Deleuze and Guattari. New Formations 69 (1): 111-128.

Sundberg, J. 1998. NGO landscapes in the Maya Biosphere Reserve, Guatemala. Geographical Review 88 (3): 388-412.

Szablowski, D. 2002. Mining, displacement and the World Bank: a case analysis of Compania Minera Antamina's operations in Peru. Journal of Business Ethics, 39 (3): 247-273.

Terborgh, J. 1999. Requiem for nature. Washington DC: Island Press. review

UNFCCC. 2007. Climate change: impacts, vulnerabilities and adaption in developing countries. Bonn: United Nations Framework Convention on Climate Change.

Uphoff, N. and Langholz, J. 1998. Incentives for avoiding the tragedy of the commons. Environmental Conservation 25 (03): 251-61.

Vaccaro, I., Beltran, O., and Paquet, P.A. 2013. Political ecology and conservation policies: some theoretical genealogies. Journal of Political Ecology 20: 255-272.

Wainwright, C. and Wehrmeyer, W. 1998. Success in integrating conservation and development? A study from Zambia. World Development 26 (6): 933-944.

Waitt, G. 1999. Naturalizing the 'primitive': a critique of marketing Australia's indigenous peoples as 'hunter gatherers'. Tourism Geographies 1(2): 142-163. 
WCED 1987. Our common future. Oxford and New York: World Commission on Environment and Development.

West, P. 2006. Conservation is our government now: the politics of ecology in Papua New Guinea. Duke University Press.

Western, D. and Wright, R.M. 1994. Natural connections: perspectives in community-based conservation. Washington, DC: Island Press.

Wilshusen, P.R., Brechin, S.R., Fortwangler, C.L., and West, P.C. 2002. Reinventing a square wheel: critique of a resurgent "protection paradigm" in international biodiversity conservation. Society and Natural Resources 15 (1): 17-40.

Young, K.R. and León, B. 1999. 1999. Peru's Humid Eastern Montane Forests: an overview of their physical settinas, biological diversity, human use and settlement, and conservation needs. DIVA Technical Report 5. Kalø, Denmark: Centre for Research on Cultural and Biological Diversity of Andean Rainforests (DIVA). related

Zimmerer, K.S. 1997. Changing fortunes: biodiversity and peasant livelihood in the Peruvian Andes. Berkeley: University of California Press.

\begin{abstract}
Northeastern Peru is considered a global conservation priority due to high biodiversity and acute threats to natural habitat. Its non-indigenous migrant populations, known as campesinos, are presented by mainstream conservation agents as the major threat to this area, as environmentally destructive, apathetic to nature, and only responsive to economic and material incentives.

But the campesinos of Northeastern Peru often initiate their own conservation projects, justifying these actions with moral rationales. I divided these into anthropocentric and ecocentric categories. Justifications included an appreciation of nature's intrinsic values, religious or spiritual value, an aspiration for sustainability and a concern for future generations. I found that conservation is also seen as part of the struggle for social justice and recognition. Monetary incentives promoted by mainstream conservation agents were generally perceived in three ways: 1 ) as an opportunity for personal economic gain; 2) as an opportunity to sustain otherwise unaffordable conservation activities; 3 ) and when conservation was part of a social struggle economic incentives were perceived as unnecessary, undesirable or even a hindrance. Governmental legislation and outside conservation agents generally remain biased towards using economic justifications for local initiatives.

I used social methodologies to record campesino justifications for conservation and their interactions with conventional conservation. My aim was to categorize and analyze campesino views on conservation, highlighting those which challenge mainstream conservation, political ecologists' paradigms, and those that offer alternatives for collaboration with local populations towards shared goals.
\end{abstract}

Keywords: Conservation, environmental ethics, Peru, ecocentrism, anthropocentrism, neoliberal conservation, local participation. 


\section{Résumé}

Le Nord-Est du Pérou est considéré comme une priorité mondiale pour le conservation, en raison de sa grande biodiversité et menaces aiguës pour l'habitat. Les paysans, qui sont les migrants de la région et nonautochtones, sont présentées par des agents de conservation traditionnels comme la principale menace pour cette région: destructrice de l'environnement, apathique à la nature et seulement sensible aux incitations économiques et matérielles.

Mais les paysans du nord-est du Pérou initient souvent leurs propres projets de conservation, ce qui justifie ces actions avec les justifications morales. J'ai divisé ces derniers dans les catégories anthropocentriques et écocentrique. Leurs justifications compris une appréciation des valeurs intrinsèques de la nature, sa valeur religieuse ou spirituelle, et une aspiration à la durabilité et une préoccupation pour les générations futures. J'ai trouvé que la conservation est également considérée comme faisant partie de la lutte pour la justice sociale et la reconnaissance. Les incitations monétaires promus par des agents de conservation traditionnels sont généralement perçus de trois façons: 1) comme une opportunité pour le gain économique personnel; 2) comme une occasion de soutenir les activités de conservation autrement inabordables; 3 ) et parfois, des incitations économiques ont été perçus comme inutile, indésirable ou même une hinderance quand conservation faisait partie d'une lutte sociale. La législation du gouvernement et des organismes de conservation sont généralement biaisés vers l'utilisation de justifications économiques aux initiatives locales.

Ma méthode était d'enregistrer les justifications utilisées par les paysans pour la conservation, et de leurs interactions avec des projets de conservation conventionnels. Mon but était de catégoriser et d'analyser les points de vue des paysans, mettant en évidence ceux qui remettent en cause la pensée dominante de conservation, les paradigmes de écologistes politiques, et ceux qui offrent des solutions de collaboration avec les populations locales vers des objectifs communs.

Mots-clés: Conservation, l'éthique de l'environnement, le Pérou, écocentrisme, l'anthropocentrisme, la conservation néolibérale, la participation locale.

\section{Resumen}

El noroeste del Perú es considerado una prioridad de conservación a nivel mundial, debido a la alta biodiversidad y las graves amenazas que se presentan. Poblaciones migrantes, mestizos, conocidos como campesinos son presentados por los agentes de conservación convencional como la principal amenaza a este sector, destructores del medio ambiente, apáticos con la naturaleza y únicamente interesados en incentivos económicos y materialistas.

Los campesinos del noreste de Perú suelen iniciar sus propios proyectos de conservación, justificando estas acciones con argumentos morales. Dividí éstos en categorías antropocéntrica y ecocéntrica. Las justificaciones incluían una apreciación de los valores intrínsecos de la naturaleza, valor religioso o espiritual, aspiración a la sostenibilidad y preocupación por las generaciones futuras. He encontrado que la conservación también es vista como parte de la lucha por la justicia y el reconocimiento social. Los incentivos monetarios promovidos por los agentes de conservación convencional se perciben generalmente de tres maneras: 1) La oportunidad para obtener ganancias económicas personales, 2) Como una oportunidad para sostener las actividades de conservación de otro modo inalcanzables, 3) Cuando la conservación forma parte de un conflicto social, donde se perciben los incentivos económicos como innecesarios, indeseables o incluso como obstáculos. La legislación gubernamental y agentes de conservación externos, generalmente se encuentran inclinados a iniciativar las actvidades de conservacion local que tienen como proposito lucrar economicamente.

He utilizado metodologías sociales para recoger justificaciones de los campesinos sobre la conservación y sus interacciones con la conservación convencional. Mi objetivo fue categorizar y analizar los puntos de vista de los campesinos sobre la conservación, destacando aquellos que desafían las corrientes de conservación convencional así como los paradigmas de la ecológicia politica, que ofrecen alternativas de colaboración con la población local con metas unificadas.

Palabras clave: conservación, ética ambiental, Perú, ecocentrismo, antropocentrismo, conservación neoliberal, participación local. 